$\xi^{2}=1$.

\title{
Altitudinal runoff assessment under variable lapse rates of temperature in the Hindu Kush, Karakorum and Himalaya ranges of Pakistan
}

\author{
Arshad Ashraf \\ Climate, Energy and Water Research Institute (CEWRI), National Agricultural Research Center, Park \\ road, Chakshahzad, Islamabad, Pakistan \\ E-mail: mashr22@yahoo.com
}

\begin{abstract}
Snow and glaciers form a major source of fresh water for sustenance of millions of people in the Hindu Kush, Karakoram and Himalaya (HKH) region. The meltwater supplies are highly vulnerable to changing climate which may affect irrigated agriculture, livelihoods and natural ecosystems in the region. In the present study, a correlation between ice-melt runoff, glacier area and mean temperature was developed and applied to assess glacier-melt runoff using lapse rates of temperature (LRT) in 10 river basins of the HKH ranges of Pakistan The LRT of ablation period was determined about $-0.39^{\circ} \mathrm{C} / 100 \mathrm{~m}$ in the Hindu Kush, $-0.67^{\circ} \mathrm{C} / 100 \mathrm{~m}$ in the Karakoram and $-0.59^{\circ} \mathrm{C} / 100$ $\mathrm{m}$ in the Himalayas. Maximum ice-melt runoff was estimated from $4500-5000 \mathrm{~m}$ in seven basins, whereas it was maximum from 5000$5500 \mathrm{~m}$ elevation range in two basins. In Jhelum basin, the runoff was found maximum from 4000-4500 m elevation range. Overall, about $28.3 \%$ of the glacier-melt appears to generate from $5000-5500 \mathrm{~m}$ and $27.8 \%$ from $4500-5000 \mathrm{~m}$ elevation range in all three HKH ranges. However, thorough glacio-hydrological studies are essential in context of possible changes in climate and land use for effective water resource management in this region in future.
\end{abstract}

Keywords: Cryosphere; Glacier-Melt; Himalaya; Hindu Kush; Karakoram.

\section{Introduction}

The glaciers of Himalayan region influence the runoff regimes of major river systems in the high Asia like Indus, Ganges, Amu Darya, Brahmaputra, Irrawaddy, Mekong rivers (Immerzeel et al. 2010, Kaser et al. 2010, Pritchard 2017). Receding of glaciers in most of the Himalayas and a general shrinkage on a global scale have been observed during last few decades (WWF 2005, 2001, Ren et al. 2006, Kargel et al. 2011, Bolch et al. 2012, Yao et al. 2012, Bajracharya et al. 2015, Pratap et al. 2015). The changes in glacier behavior ultimately effect the ice-melt flows in the downstream (Winiger 2005, Immerzeel et al. 2010, Kargel et al. 2011). Under projected future changes in climate, a general increase in runoff is consistently demonstrated across all basins until around the mid-21st century, owing to changes in precipitation and/or accelerated melt (Immerzeel et al. 2010, Lutz et al. 2014). However, as glacier area decreases, late spring and summer discharges will eventually reduce considerably, particularly for the Indus and Brahmaputra basins, with potentially severe consequences for food security (Immerzeel et al. 2010). Glacio-fluvial water in the Hindu Kush, Karakoram and Himalaya (HKH) Ranges is generally utilized to sustain gravity flow kuhl irrigation system by local communities (WAPDA 1988, NASED 2003, Ashraf \& Batool 2019, Nüsser et al. 2019). The glacier-melt flows are mainly high in warm summer months in the Karakoram and western Himalaya, and in the dry-season spring and autumn months in most of the central and eastern Himalaya (Immerzeel et al. 2010). Forsythe et al. (2012) highlighted the contrasting controls of temperature and precipitation on the annual hydrological cycle of the Himalayan region. Their findings point toward strong correlation between summer discharge and winter precipitation and between summer discharge and concurrent temperature in the UIB catchments. However, there is a need to assess ice-melt runoff from the three HKH ranges to support water management endeavors in this region in future.

Lapse rate of temperature is an important factor for assessing melt water runoff (Hock 2005, Immerzeel et al. 2014). This approach is used to infer air temperature at various elevations of glacier occurrence from meteorological records (Braithwaite et al. 2006, Mihalcea et al. 2006, Forsythe et al. 2010, Mukhopadhyay \& Dutta 2010, Kattel et al. 2013). Variability in air temperature in elevated catchments of Himalayan region has been studied for glacier-melt generation by Heynen et al. (2016). Ahsan et al. (2016) studied hydrological impacts resulting from altitudinal variability and changing climate and found large differences in climate owing to local climate and topographic settings in the UIB. According to Liu et al. (2009), elevation dependent warming (EDW) is not consistent across different mountainous regions of the world. The regional heterogeneity of EDW is thought to be a function of various physical temperature relevant processes such as snow albedo and surface based feedbacks, water vapor changes and latent heat release, aerosols and others (MRI EDW Working Group 2015). Such understanding has been limited owing to decrease in numbers of meteorological stations with increasing altitudes in this region. There are few case studies for calculation of runoff rates of specific glaciers in the HKH region (e.g. Hewitt et al. 2005, Mayer et al. 2006, Bookhagen \& Burbank 2010, Immerzeel et al. 2010). As these studies have minimal sample size, representing largest glac- 
iers only, the representation of their results for the entire basin is not clear. No comprehensive basin-wide assessment of glacier runoff has been carried out for the HKH region (Savoskul \& Smakhtin 2013).

The present study is focused on investigating glacier-melt runoff from various altitudinal ranges using lapse rate of temperature (LRT) of ablation period to support cryosphere-fed kuhl irrigation system in the three HKH ranges. The study area consists of 10 glaciated subbasins of Upper Indus basin (UIB) of Pakistan, within elevation range of $366 \mathrm{~m}$ in the south to more than 8,000 $\mathrm{m}$ toward northeast (Fig. 1). Most parts of the study area are semi-dry to dry receiving annual rainfall between 200 and $500 \mathrm{~mm}$ in the valleys (Khan 2014), however snowfall dominates above 3,000 $\mathrm{m}$ (Singh et al. 1995). The communities in arid environment like in Bindogol valley of Chitral basin have to depend on melt water of high mountain glaciers for their sustenance (Fig. 2). Extensive glacio-fluvial water is available for irrigation use during summer months, i.e., from June to September, when contribution of snow/glacier melt to stream is usually high (SDPI 2002, Zulfiqar et al. 2019).

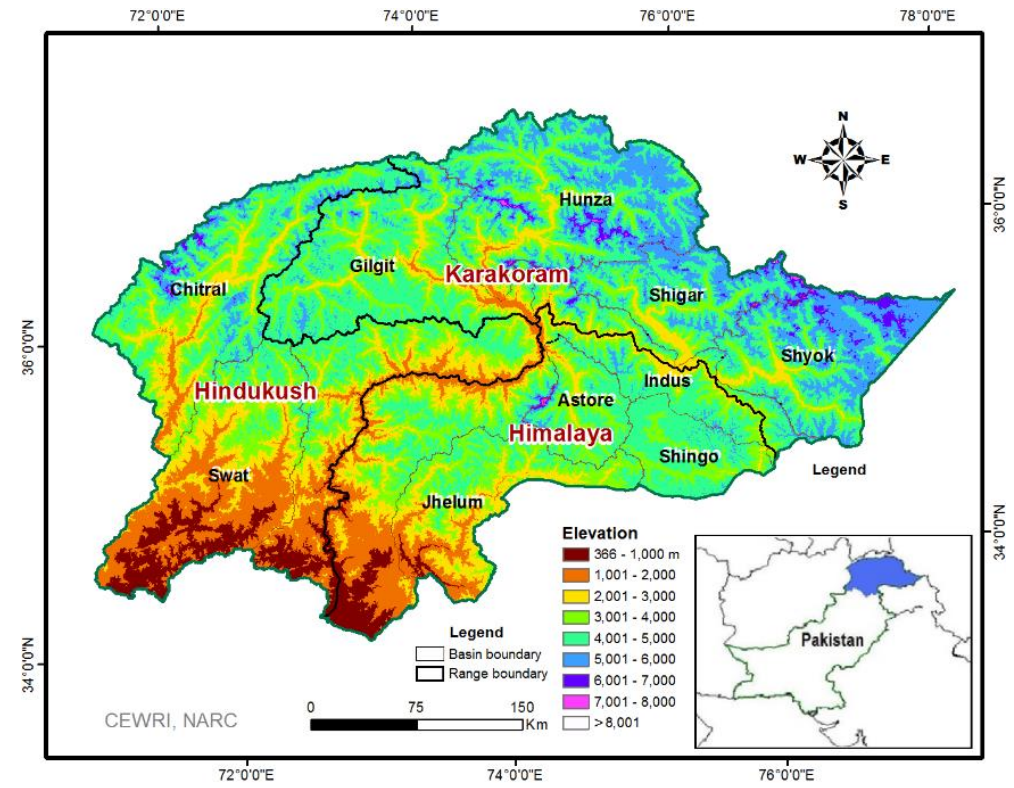

Fig. 1: Location of the Three HKH Ranges with River Basins in Northern Pakistan.

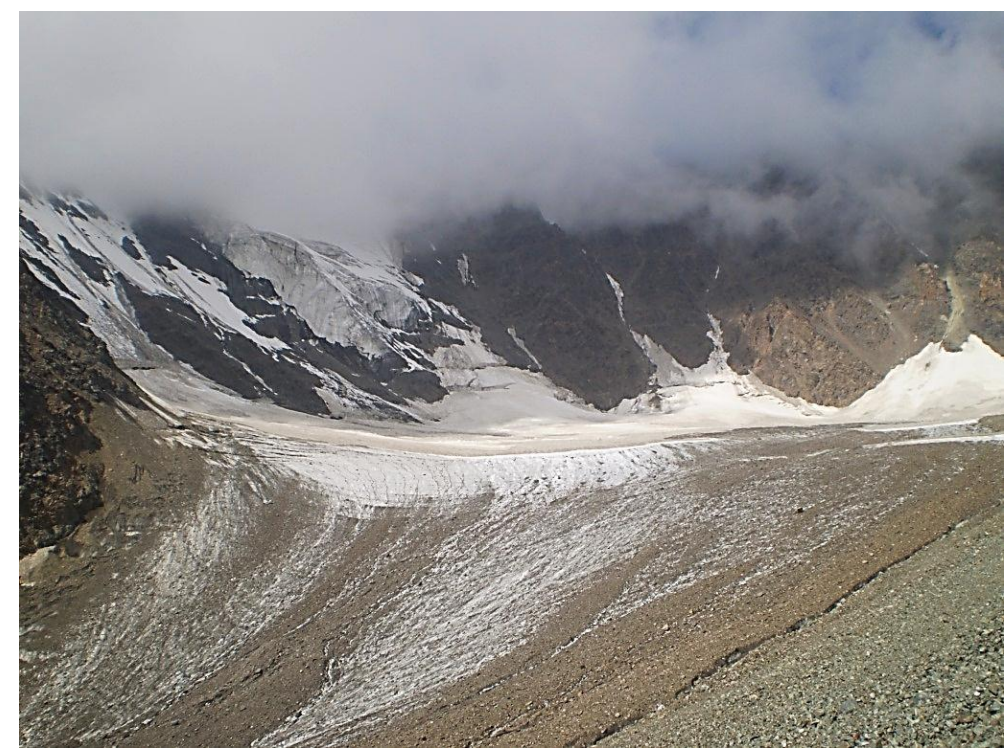

Fig. 2: Ice-Melt from High Mountain Glacier like Bindogol (Elevation: 4450-4629 m) in Chitral Basin is a Major Source of Water Supply for Sustenance of Many Communities residing in the Downstream.

\section{Data and methodology}

The climate data of 20 meteorological stations (1990-2014 period) covering the study area was acquired from Pakistan Meteorological Department (PMD) and Water and Power Development Authority (WAPDA) for LRT analysis in the HKH ranges. The stations fall within elevation range of 702-4730 m. The discharge data of the rivers on daily time scale since 1980 was acquired from Surface water hydrology project (SHWP) of WAPDA. The source data of glaciers was acquired from glacier inventory developed by ICIMOD (2011) for Indus basin using Landsat 8 OLI satellite imageries of 2005+3 period. Digital elevation model (DEM) of Shuttle Radar Topography Mission (SRTM) (90 m resolution) was downloaded for topographic analysis and to study altitudinal variations of temperature in the three Himalayan ranges.

In order to estimate vertical distribution of runoff in 10 river basins, lapse rates of temperature were determined for all three $\mathrm{HKH}$ ranges by performing regression analysis between temperature and elevation data on monthly, seasonal and annual time-scales. As temperature typically decreases with elevation, the altitudinal lapse rate of temperature measured in ${ }^{\circ} \mathrm{C} / 100 \mathrm{~m}$ is usually negative (Fang \& Yoda 
1988, Pepin 2001). Under combinations of atmospheric conditions (Lundquist et al. 2008), temperature is assumed to drop directly with elevation, as given by Eq. 1 defined by Petersen and Pellicciotti (2011).

$$
\mathrm{LRT}=\frac{\mathrm{T} 1-\mathrm{T} 2}{\mathrm{Z} 1-\mathrm{Z} 2}=\frac{\mathrm{dT}}{\mathrm{dZ}}
$$

Where $\mathrm{T} 1$ and $\mathrm{T} 2$ are the higher and lower points temperatures at Z1 and Z2 elevations $(\mathrm{m})$ respectively. The reason of decreasing temperature with increased elevation is that when air is blown upwards from the low altitude it expands and becomes cooler due to adiabatic expansion. Statistical analysis using linear regression method was performed to determine LRT on monthly and annual basis. The strength of relationship between temperature and elevation was evaluated using coefficient of determination $\left(\mathrm{R}^{2}\right)$, Pearson's correlation coefficient $(\mathrm{R})$ and statistical significance value $(\mathrm{P})$. The mean temperature was determined of the ablation period (June-September) at the lowest main climate station of each river basin to assess vertical runoff using LRT approach.

In the total annual discharge of Shigar river, contribution of glacier-melt runoff was 88-95\% during June-September (ablation period). Mean runoff per $\mathrm{km}^{2}$ of glacier area was determined by dividing mean annual discharge of June-September period (about $\left.651.1 \mathrm{~m}^{3} / \mathrm{s}\right)$ by total glacier area of the Shigar basin (i.e., about $2485.7 \mathrm{~km}^{2}$ ). At mean temperature $\mathrm{T}_{\mathrm{b}}$ (about $21.2^{\circ} \mathrm{C}$ ) of June-September (ablation period), mean runoff per $\mathrm{km}^{2}$ of glacier area was assessed about $0.26 \mathrm{~m}^{3} / \mathrm{s}$ for Shigar basin. This unit runoff from glaciated area of Shigar provided base for estimating mean runoff $\mathrm{Q}$ from glacier area A via Eq. 2.

$\mathrm{Q}=0.26 * \mathrm{~T}_{\mathrm{i}} * \mathrm{~A} / \mathrm{T}_{\mathrm{b}}$

Where, $T_{i}$ is mean temperature determined at base elevation of different stations in 9 river basins and $T_{b}$ is the mean temperature (about $21.2^{\circ} \mathrm{C}$ ) at base station in the Shigar basin.

\section{Results and discussion}

\subsection{LRT Analysis by HKH ranges}

The lapse rate of temperature, coefficient correlation $\mathrm{R}$ and temperatures at zero elevation were determined for the three $\mathrm{HKH}$ ranges using climate data of 1990-2014 period (Table 1). Highly glaciated Shigar river basin (34\% glacier cover) was selected as base for estimation of glacier-melt runoff from unit glacier area $\left(\mathrm{km}^{2}\right)$ using mean temperature of ablation period (June-September) of about $21.2^{\circ} \mathrm{C}$ at Shigar station (Elevation: $2300 \mathrm{~m}$ ). According to Ashraf and Iqbal (2018), glacial reserve per unit glacier was found maximum in the Shigar basin (i.e., $1.44 \mathrm{~km}^{3}$ ). In the total annual discharge of Shigar river (Fig. 3), contribution of glacier-melt runoff was $88-95 \%$ during June-September (ablation period).

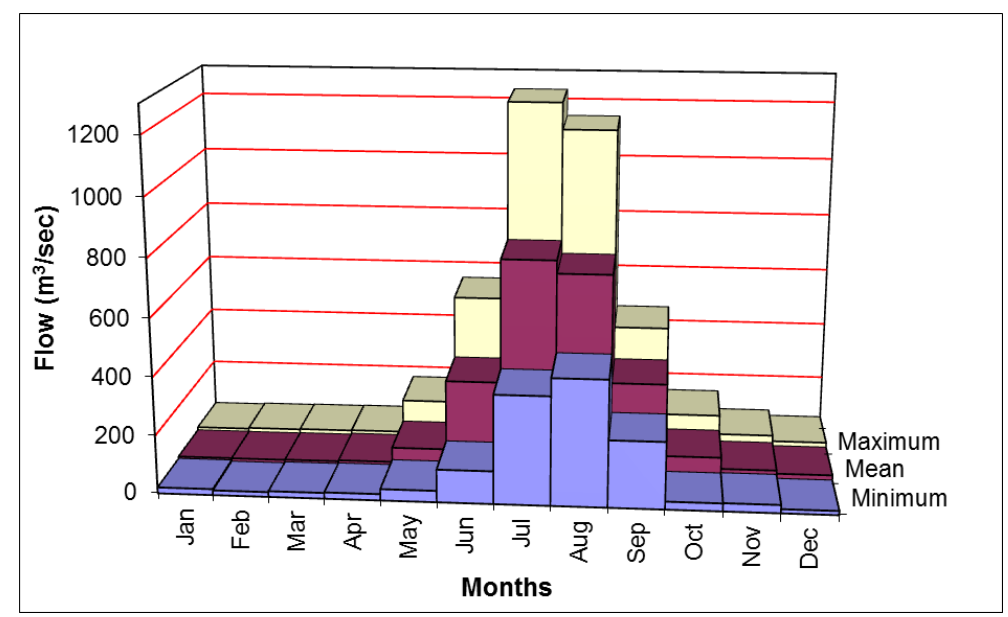

Fig. 3: Mean Monthly Variations in Shigar River Discharge in Eastern Karakoram.

In the Hindu Kush range, mean monthly LRT ranged within $-0.28--0.76^{\circ} \mathrm{C} / 100 \mathrm{~m}$ (the former in month of August and the latter in month of April), while it was $-0.56^{\circ} \mathrm{C} / 100 \mathrm{~m}$ at annual level (Fig. 4). The LRT during ablation period (June-September) was determined about $-0.39^{\circ} \mathrm{C} / 100 \mathrm{~m}$. The reason of low values of LRT in this mountain range may be attributed to less glacial coverage and presence of urban settlements along Chitral and Swat rivers resulting in higher GHG emissions ultimately exaggerating warm temperatures. Temperature at zero elevation $\mathrm{C}$ varied between $16.8^{\circ} \mathrm{C}$ and $33.4^{\circ} \mathrm{C}$ (minimum for December and maximum for June), and overall $23.6^{\circ} \mathrm{C}$ at annual level. In the Karakoram range, mean monthly LRT ranged within $-0.62--0.70^{\circ} \mathrm{C} / 100 \mathrm{~m}$ (the former in months of January and December and the latter in months of March, May and June), while it was $-0.71^{\circ} \mathrm{C} / 100 \mathrm{~m}$ at annual level. The LRT during ablation period (June-September) was determined about $-0.67^{\circ} \mathrm{C} / 100 \mathrm{~m}$.

The higher values of LRT in the Karakoram may be attributed to higher altitudes, presence of extensive glacier coverage and higher latitudes. Similarly low emission of greenhouse gasses due to scarce urban development is also causing significant difference between low and high vertical temperatures in this mountain range. A decrease in concentration of greenhouse gases may cause lowering of heat absorption capacity of atmosphere, ultimately resulting in reduction of warm temperature. Temperature at zero elevation $\mathrm{C}$ varied between $12.9^{\circ} \mathrm{C}$ and $38.5^{\circ} \mathrm{C}$ (minimum for January and maximum for July), and overall $27.5^{\circ} \mathrm{C}$ at annual level (Fig. 5). In the Himalaya range, mean monthly LRT ranged from -0.52 to $-0.7^{\circ} \mathrm{C} / 100 \mathrm{~m}$ (the former in month of August and the latter in month of April), while it was $0.59^{\circ} \mathrm{C} / 100 \mathrm{~m}$ at annual level. The LRT during ablation period (June-September) was determined about $-0.59^{\circ} \mathrm{C} / 100 \mathrm{~m}$. Owing to lower latitude and altitude, and higher temperatures, glacier coverage is less pronounced that may result in low values of LRT in this mountain range. 
Table 1: Mean Temperature at Zero Elevation C $\left({ }^{\circ} \mathrm{C}\right)$, LRT $\left({ }^{\circ} \mathrm{C} / 100 \mathrm{~m}\right)$ and Correlation Coefficient $\mathrm{R}$ for the Three HKH Ranges.

\begin{tabular}{|c|c|c|c|c|c|c|c|c|c|c|c|c|}
\hline \multirow{2}{*}{ Month/ Range } & \multicolumn{3}{|c|}{ Hindu Kush } & \multicolumn{3}{|c|}{ Karakoram } & \multicolumn{3}{|c|}{ Himalaya } & \multicolumn{3}{|c|}{ HKH Region } \\
\hline & $\mathrm{C}$ & LRT & $\mathrm{R}$ & $\mathrm{C}$ & LRT & $\mathrm{R}$ & $\mathrm{C}$ & LRT & $\mathrm{R}$ & $\mathrm{C}$ & LRT & $\mathrm{R}$ \\
\hline Jan & 15.2 & -0.72 & -0.987 & 12.9 & -0.62 & -0.998 & 15.1 & -0.69 & -0.984 & 14.6 & -0.67 & -0.991 \\
\hline Feb & 16.7 & -0.71 & -0.988 & 16.7 & -0.66 & -0.998 & 17.1 & -0.69 & -0.989 & 16.6 & -0.67 & -0.993 \\
\hline Mar & 19.3 & -0.58 & -0.963 & 22.5 & -0.70 & -0.998 & 21.6 & -0.69 & -0.986 & 21.0 & -0.65 & -0.990 \\
\hline Apr & 26.6 & -0.76 & -0.973 & 27.3 & -0.68 & -0.987 & 26.8 & -0.70 & -0.986 & 26.1 & -0.66 & -0.985 \\
\hline May & 29.6 & -0.59 & -0.926 & 32.4 & -0.70 & -0.995 & 31.3 & -0.67 & -0.983 & 31.2 & -0.67 & -0.989 \\
\hline Jun & 33.4 & -0.54 & -0.838 & 36.2 & -0.70 & -0.991 & 34.6 & -0.67 & -0.978 & 34.9 & -0.67 & -0.982 \\
\hline Jul & 30.8 & -0.29 & -0.464 & 38.5 & -0.67 & -0.988 & 34.0 & -0.57 & -0.926 & 34.6 & -0.57 & -0.940 \\
\hline Aug & 29.7 & -0.28 & -0.421 & 37.6 & -0.67 & -0.989 & 32.7 & -0.52 & -0.911 & 33.5 & -0.54 & -0.934 \\
\hline Sep & 28.8 & -0.44 & -0.731 & 32.8 & -0.64 & -0.987 & 31.0 & -0.59 & -0.962 & 31.2 & -0.59 & -0.972 \\
\hline Oct & 23.9 & -0.48 & -0.836 & 27.8 & -0.68 & -0.990 & 26.4 & -0.63 & -0.975 & 26.5 & -0.64 & -0.982 \\
\hline Nov & 17.5 & -0.46 & -0.717 & 21.0 & -0.65 & -0.989 & 21.2 & -0.64 & -0.978 & 20.7 & -0.63 & -0.978 \\
\hline Dec & 16.8 & -0.67 & -0.954 & 15.2 & -0.62 & -0.994 & 16.4 & -0.64 & -0.975 & 16.4 & -0.65 & -0.986 \\
\hline Annual & 23.6 & -0.56 & -0.780 & 27.5 & -0.71 & -0.985 & 23.9 & -0.59 & -0.969 & 24.6 & -0.62 & -0.972 \\
\hline
\end{tabular}

The controlling factors of LRT in the Himalayan region are also described by researchers like Kattel et al. (2013) and Heynen et al. (2016). Temperature at zero elevation $\mathrm{C}$ varied between $15.1^{\circ} \mathrm{C}$ and $34.6^{\circ} \mathrm{C}$ (minimum for January and maximum for June), and overall $23.9^{\circ} \mathrm{C}$ at annual level (Table 1 and Fig. 5). The pattern of monthly LRT of the Himalayas appears identical to that of the whole HKH region that ranged from $-0.54{ }^{\circ} \mathrm{C} / 100 \mathrm{~m}$ to $-0.67^{\circ} \mathrm{C} / 100 \mathrm{~m}$ at monthly and $-0.62^{\circ} \mathrm{C} / 100 \mathrm{~m}$ at annual level (Fig. 4). The correlation coefficient $(\mathrm{R})$ indicated a strong correlation $(\mathrm{R}$ values $>-0.9)$ between the temperature and elevation especially in the Karakoram and Himalaya ranges. Although LRT in the three HKH ranges vary as a function of energy balance regimes, i.e., radiative conditions, aspects, latitude, elevation, air moisture content and wind speed, but observations of some of those parameters are scarce owing to complex topography and harsh climate in the ranges. However links between hydro-glacial, orographic and climatic factors need an in-depth investigation in order to get insight of diverse situation of temperature variations in the HKH.

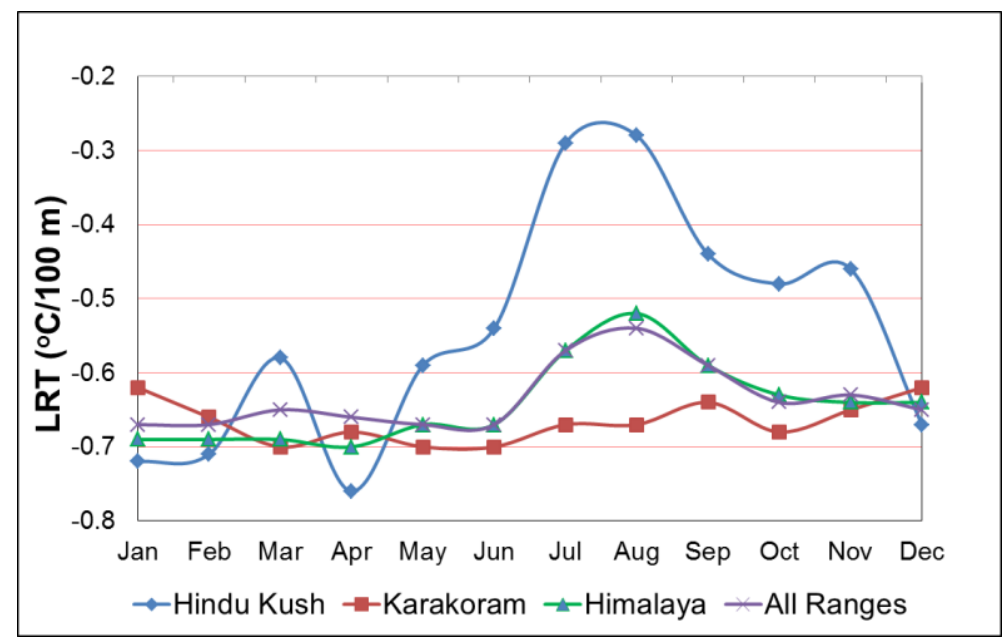

Fig. 4: Mean Monthly Variations in Lapse Rate of Temperature in Three HKH Ranges.

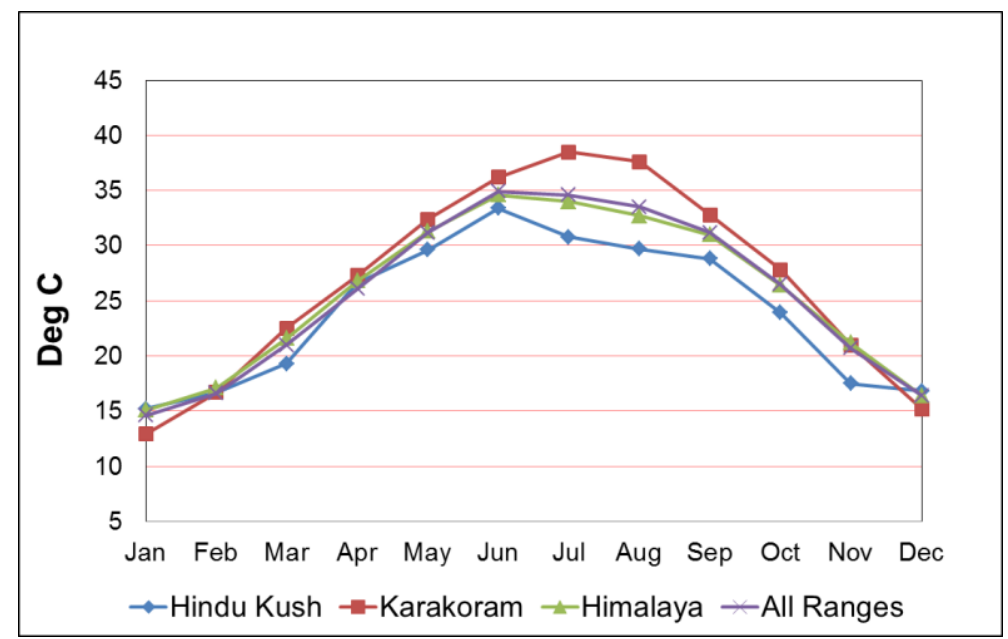

Fig. 5: Mean Monthly Temperature at Zero Elevation in Three HKH Ranges.

\subsection{Glacier-melt runoff by altitude}

The LRT values of June-September (ablation period) at $100 \mathrm{~m}$ interval in the three HKH ranges were converted into $500 \mathrm{~m}$ elevation interval using temperature data of respective meteorological station of the basin (shown in Table 2). Mean temperature varies from 8 to $30.9^{\circ} \mathrm{C}$ at these climate stations lying mainly within elevation range of $702-4356 \mathrm{~m}$. The mean LRT come out to be $-1.94^{\circ} \mathrm{C} / 500 \mathrm{~m}$ for the Hindu Kush, $-3.35^{\circ} \mathrm{C} / 500 \mathrm{~m}$ for the Karakoram and $-2.94^{\circ} \mathrm{C} / 500 \mathrm{~m}$ for the Himalaya range, which were used to determined mean temperature of ablation period $\mathrm{T}_{\mathrm{i}}$ at other climate stations equivalent at base elevation of the Shigar station. 
Table 2: Distribution of Glacier Coverage and Mean Temperature of Ablation Period in Different HKH Basins

\begin{tabular}{|c|c|c|c|c|c|c|}
\hline Basin & Geographic Area $\left(\mathrm{km}^{2}\right)$ & Glacier Area $\left(\mathrm{km}^{2}\right)$ & Gr Area $\%$ & Climate station & Elevation $(\mathrm{m})$ & $\mathrm{T}_{\text {mean }}{ }^{\circ} \mathrm{C}$ \\
\hline Swat & 14245.1 & 131.3 & 0.9 & Saidu Sharif & 961 & 27.1 \\
\hline Chitral & 14705.1 & 1527.2 & 10.4 & Drosh & 1464 & 28.1 \\
\hline Gilgit & 14076.6 & 970.8 & 6.9 & Gilgit & 1460 & 24.8 \\
\hline Shigar & 7366.1 & 2485.7 & 33.7 & Shigar & 2300 & 21.2 \\
\hline Shyok & 9953.2 & 2967.6 & 29.8 & Hushey & 2995 & 16.9 \\
\hline Indus & 32569.8 & 750.8 & 2.3 & Chilas & 1250 & 30.9 \\
\hline Shingo & 4681.5 & 41.3 & 0.9 & Deosai & 4356 & 8.0 \\
\hline Jhelum & 9197.0 & 128.5 & 1.4 & Muzaffarabad & 702 & 28.3 \\
\hline Total/Avg. & 127210.0 & 12130.9 & 9.5 & - & - & - \\
\hline
\end{tabular}

The glacier coverage was determined at each elevation band of $500 \mathrm{~m}$ in the HKH basins (Table 3). Maximum glacier coverage in Swat, Chitral, Gilgit, Shigar, Indus, Shingo and Astore basin lie within elevation range of 4500-5000 m, whereas in Hunza and Shyok, it lies within 5000-5500 $\mathrm{m}$ and in Jhelum basin within 4000-4500 m elevation range. In general the glacier coverage is contributed by the valley type glaciers in the Karakoram basins and the Chitral basin of the Hindu Kush. For example, Hunza, Shyok, Shigar and Chitral basins possessing about $2875.0 \mathrm{~km}^{2}, 2967.6 \mathrm{~km}^{2}, 2485.7 \mathrm{~km}^{2}, 1527.2 \mathrm{~km}^{2}$ glaciated area (Table 2), contain majority of the valley glaciers, i.e., 201, 52, 46 and 125 numbers respectively. Owing to their bulk ice mass, the valley glaciers indicated a fair positive correlation with the total glacier coverage of those river basins (e.g. coefficient of determination $\mathrm{R}^{2}$ value of 0.67 ) significant at $\mathrm{p}<0.05$. As a whole in all basins, maximum glacier coverage (about $\left.3456 \mathrm{~km}^{2}\right)$ exists within $5000-5500 \mathrm{~m}$ followed by $4500-5000 \mathrm{~m}$ elevation range $\left(3320 \mathrm{~km}{ }^{2}\right)$. In general, the Karakorum glaciers are affected by two distinct sets of climate controls, e.g. the first derives from location with respect to the circulation of the atmosphere and their air masses entering the region, and the second sets involves the high mountain terrain and such affected as the typical Orographic lifting, obstructing and funneling of air movement (Hewitt 2005). Due to high altitudinal mountainous terrain, the sun time is short and nights are cold, which make glaciers to grow rather than to retreat in the Karakoram. Generally, large valley glaciers in the Karakoram range like Siachen, Baltoro, Biafo, Hispar, Batura and Chogo Lungma, extend down to lower elevations (below $3500 \mathrm{~m}$ ) and possess bulk of the ice reserves, the existence of which exhibits stable and conducive climatic conditions for glacial formation in the Karakoram (e.g. Hewitt 2005, 2010; Kääb et al. 2012; Gardelle et al. 2013). Several researchers reported increasing trends in winter precipitation from $600 \mathrm{~mm}$ to more than $1700 \mathrm{~mm}$, especially in elevations above $4000 \mathrm{~m}$ (Cramer 1993, Winiger et al. 2005, Tahir et al. 2011).

Table 3: Distribution of Glacier Coverage $\left(\mathrm{km}^{2}\right)$ by Altitude in Different HKH Basins

\begin{tabular}{|c|c|c|c|c|c|c|c|c|c|c|c|}
\hline Elevation $(\mathrm{m})$ & Swat & Chitral & Gilgit & Hunza & Shigar & Shyok & Indus & Shingo & Astore & Jhelum & Total \\
\hline $7500-8000$ & 0.0 & 0.2 & 0.5 & 2.9 & 5.3 & 0.3 & 0.8 & 0.0 & 1.5 & 0.0 & 11.5 \\
\hline $7000-7500$ & 0.0 & 10.1 & 1.3 & 22.2 & 18.3 & 10.2 & 4.1 & 0.0 & 1.7 & 0.0 & 67.9 \\
\hline $6500-7000$ & 0.0 & 31.6 & 6.8 & 72.8 & 45.0 & 56.3 & 10.1 & 0.0 & 3.8 & 0.0 & 226.4 \\
\hline $6000-6500$ & 0.0 & 54.1 & 20.1 & 155.3 & 122.7 & 241.4 & 23.9 & 0.0 & 7.0 & 0.0 & 624.5 \\
\hline $5500-6000$ & 0.6 & 120.4 & 54.9 & 481.3 & 334.1 & 822.9 & 34.8 & 0.0 & 13.7 & 0.3 & 1863.0 \\
\hline $5000-5500$ & 7.0 & 388.2 & 184.7 & 928.4 & 650.9 & 1108.9 & 125.4 & 5.2 & 34.6 & 3.7 & 3437.0 \\
\hline $4500-5000$ & 60.9 & 598.7 & 425.2 & 608.0 & 678.7 & 526.6 & 292.6 & 35.1 & 105.1 & 40.7 & 3371.6 \\
\hline $4000-4500$ & 55.4 & 261.5 & 190.7 & 331.7 & 431.8 & 152.4 & 188.5 & 1.0 & 69.3 & 74.6 & 1756.9 \\
\hline $3000-3500$ & 0.1 & 4.4 & 22.4 & 76.1 & 32.5 & 1.9 & 23.4 & 0.0 & 3.4 & 0.1 & 164.3 \\
\hline $2500-3000$ & 0.0 & 0.0 & 3.1 & 18.7 & 4.4 & 0.0 & 1.7 & 0.0 & 0.1 & 0.0 & 28.0 \\
\hline $2000-2500$ & 0.0 & 0.0 & 0.0 & 0.6 & 0.0 & 0.0 & 0.0 & 0.0 & 0.0 & 0.0 & 0.6 \\
\hline Total & 131.3 & 1527.4 & 970.8 & 2875.2 & 2485.6 & 2967.6 & 750.8 & 41.3 & 252.7 & 128.5 & 12131.2 \\
\hline
\end{tabular}

The glacier coverage existing at lower elevations, e.g. ranging between 0.1 and $18.7 \mathrm{~km}^{2}$ within $2500-3000 \mathrm{~m}$ elevation range in five river basins (Gilgit, Hunza, Shigar, Indus and Astore) and between $0.1 \mathrm{~km}^{2}$ and $76.1 \mathrm{~km}^{2}$ within $3000-3500 \mathrm{~m}$ in the majority of river basins (Table 3) appears to have benefit for irrigated agriculture. Overall high accessibility index of glaciers (minimum elevation below $3500 \mathrm{~m}$ ) for developing kuhl irrigation system was found in $1 \%$ glaciers only constituting $43.4 \%$ ice reserves in the three HKH ranges (Ashraf \& Iqbal 2018). Additional to the impacts of changing cryosphere related runoff on agriculture, the Himalayan agro-ecosystems have been stressed through higher mean annual temperatures, altered precipitation patterns, and frequent extreme weather events (Ouyang 2012, IPCC 2014). This situation demands sufficient number of meteorological and discharge measuring stations installed in the hydrologically complex and scarce high elevation climate data regime.

The mean temperatures determined at base elevations of different climate stations were used to assess discharge Q from glacier area of different elevation bands following Eq. 2. The mean discharge from all HKH basins was determined over $3064.2 \mathrm{~m}^{3} / \mathrm{s}$, higher for Shyok $\left(739.2 \mathrm{~m}^{3} / \mathrm{s}\right)$, Shigar $\left(648.1 \mathrm{~m}^{3} / \mathrm{s}\right)$ and Hunza basin $\left(640.1 \mathrm{~m}^{3} / \mathrm{s}\right)$, and least for Shingo basin $\left(10 \mathrm{~m}^{3} / \mathrm{s}\right)$ (Table 4). The glacier-melt runoff appears to generate maximum from 4500-5000 m elevation range in Swat basin (about $15.9 \mathrm{~m}^{3} / \mathrm{s}$ ), Chitral basin $\left(178.4 \mathrm{~m}^{3} / \mathrm{s}\right.$ ), Gilgit basin $\left(94.7 \mathrm{~m}^{3} / \mathrm{s}\right)$, Shigar $\left(177 \mathrm{~m}^{3} / \mathrm{s}\right)$, Indus main stream $\left(90 \mathrm{~m}^{3} / \mathrm{s}\right)$, Shingo basin $\left(8.5 \mathrm{~m}^{3} / \mathrm{s}\right)$ and Astore basin $\left(24.7 \mathrm{~m}^{3} / \mathrm{s}\right)($ Table 4 and Fig. 6). In Hunza and Shyok river basins, maximum melt appears to generate from 5000-5500 m range, i.e., about $32.3 \%$ and $37.4 \%$, respectively, whereas in Jhelum river basin, maximum runoff is generated from 4000-4500 m elevation range (Fig. 7). Overall, about 28.3\% glacier-melt appears to generate from $5000-5500 \mathrm{~m}$ followed by $27.8 \%$ from $4500-5000 \mathrm{~m}$ elevation range in all the HKH ranges. The lesser glacier-melt generated in the lower basins, e.g. Swat, Indus and Jhelum may be compensated by higher intensity of precipitation occurred during summer monsoon season. The probable causes of altitudinal variations in runoff generation could be factors like changes in timing and quantity of precipitation, temperature, and land cover in the Himalayan ranges.

\begin{tabular}{|c|c|c|c|c|c|c|c|c|c|c|c|}
\hline Elevation $(\mathrm{m})$ & Swat & Chitral & Gilgit & Hunza & Shigar & Shyok & Indus & Shingo & Astore & Jhelum & Total \\
\hline $7500-8000$ & 0.0 & 0.1 & 0.1 & 0.6 & 1.4 & 0.1 & 0.2 & 0.0 & 0.4 & 0.0 & 2.9 \\
\hline $7000-7500$ & 0.0 & 3.0 & 0.3 & 4.9 & 4.8 & 2.5 & 1.3 & 0.0 & 0.4 & 0.0 & 17.2 \\
\hline $6500-7000$ & 0.0 & 9.4 & 1.5 & 16.2 & 11.7 & 14.0 & 3.1 & 0.0 & 0.9 & 0.0 & 56.9 \\
\hline $6000-6500$ & 0.0 & 16.1 & 4.5 & 34.6 & 32.0 & 60.1 & 7.4 & 0.0 & 1.6 & 0.0 & 156.3 \\
\hline $5500-6000$ & 0.2 & 35.9 & 12.2 & 107.2 & 87.1 & 205.0 & 10.7 & 0.0 & 3.2 & 0.1 & 461.5 \\
\hline
\end{tabular}




\begin{tabular}{|c|c|c|c|c|c|c|c|c|c|c|c|}
\hline $5000-5500$ & 1.8 & 115.6 & 41.1 & 206.7 & 169.7 & 276.2 & 38.6 & 1.3 & 8.1 & 0.9 & 860.1 \\
\hline $4500-5000$ & 15.9 & 178.4 & 94.7 & 135.4 & 177.0 & 131.2 & 90.0 & 8.5 & 24.7 & 9.8 & 865.5 \\
\hline $4000-4500$ & 14.5 & 77.9 & 42.5 & 73.8 & 112.6 & 38.0 & 58.0 & 0.2 & 16.3 & 17.9 & 451.7 \\
\hline $3500-4000$ & 1.9 & 17.3 & 13.6 & 39.5 & 42.2 & 11.6 & 14.0 & 0.0 & 2.9 & 2.2 & 145.3 \\
\hline $3000-3500$ & 0.0 & 1.3 & 5.0 & 16.9 & 8.5 & 0.5 & 7.2 & 0.0 & 0.8 & 0.0 & 40.2 \\
\hline $2500-3000$ & 0.0 & 0.0 & 0.7 & 4.2 & 1.1 & 0.0 & 0.5 & 0.0 & 0.0 & 0.0 & 6.5 \\
\hline $2000-2500$ & 0.0 & 0.0 & 0.0 & 0.1 & 0.0 & 0.0 & 0.0 & 0.0 & 0.0 & 0.0 & 0.1 \\
\hline Total & 34.4 & 455.0 & 216.1 & 640.1 & 648.1 & 739.2 & 231.1 & 10.0 & 59.4 & 30.8 & 3064.2 \\
\hline
\end{tabular}

Several studies points toward increase in rainfall especially around low-altitude zones in the Himalayan region except during the accumulation period (Fujita 2008, Shekhar et al. 2010, Mir et al. 2015). Furthermore, the rise in temperature at lower altitudes results in an upward shift of the $0^{\circ} \mathrm{C}$ isotherm, thereby causing more precipitation to fall as rain than as snow. Owing to rise in temperature, the ice mass is losing at unprecedented rates here (Rasul \& Chaudhry 2006). The findings of Mir et al. (2017) indicate decrease in number of snowfall in the Himalayas, which is associated with an increase in number of rainfall days.

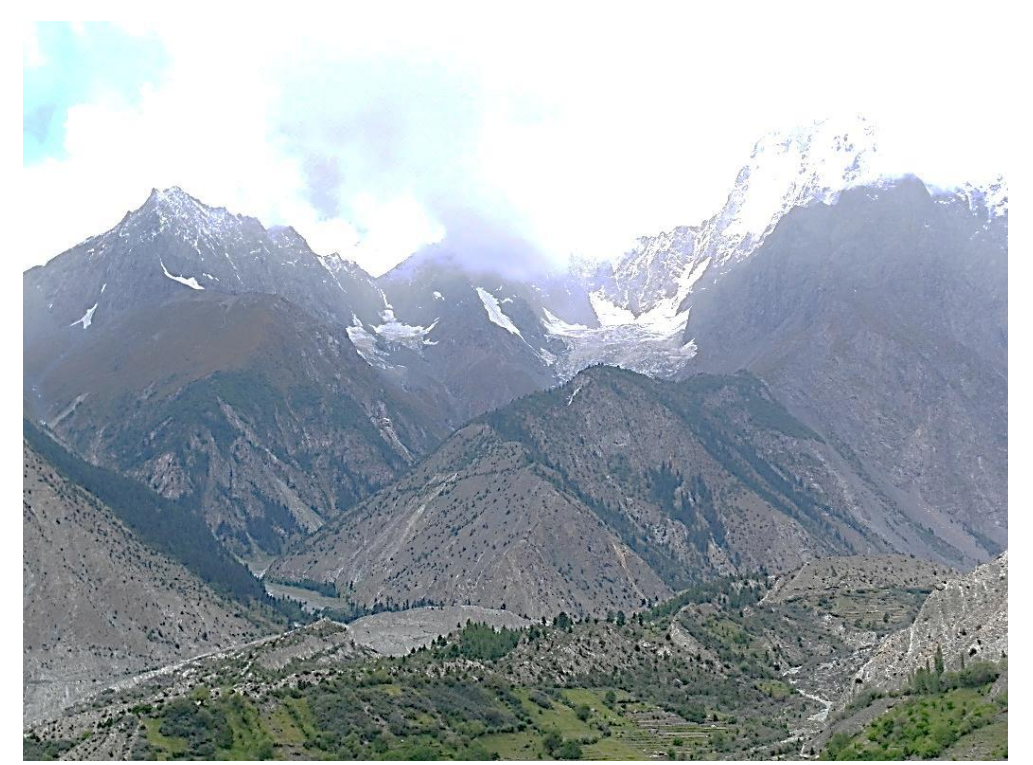

Fig. 6: Extensive Glacier-Melt Runoff is generated from 4500-5000 m Elevation Range in Gilgit River Basin, the Karakoram Range.

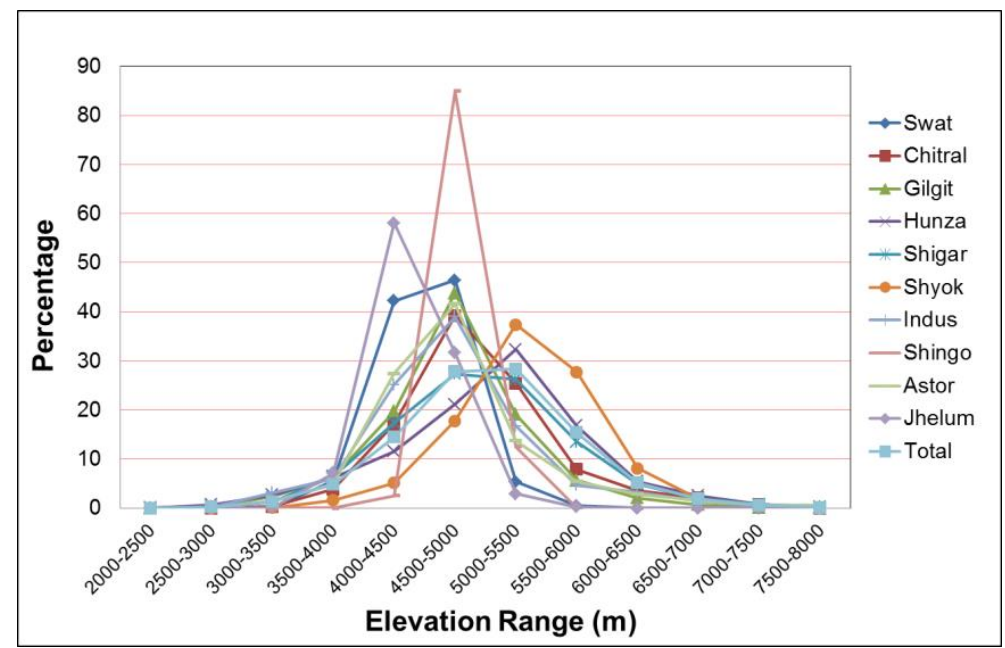

Fig. 7: Glacier-Melt Runoff Generation from Different Elevation Ranges in HKH Basins.

\section{Conclusion}

In the present study, glacier-melt runoff was assessed from various altitudinal ranges using lapse rates of temperature in the three HKH ranges of Pakistan to support irrigated agriculture and livelihoods in the downstream. The LRT during ablation period (June-September) was found about $-0.39^{\circ} \mathrm{C} / 100 \mathrm{~m}$ in the Hindu Kush, $-0.67^{\circ} \mathrm{C} / 100 \mathrm{~m}$ in the Karakoram and $-0.59^{\circ} \mathrm{C} / 100 \mathrm{~m}$ in the Himalaya range. Maximum of about $28.3 \%$ glacier-melt appears to generate from $5000-5500 \mathrm{~m}$ followed by $27.8 \%$ from $4500-5000 \mathrm{~m}$ elevation range in all three HKH ranges. The glacier-melt runoff appears to generate maximum from 4500-5000 m elevation in Swat, Chitral, Gilgit, Shigar, Indus main stream, Shingo and Astore basin, whereas it is maximum from 5000-5500 m range in Hunza and Shyok river basins. Overall, maximum of about $28.3 \%$ glacier-melt appears to generate from $5000-5500 \mathrm{~m}$ followed by $27.8 \%$ from $4500-5000 \mathrm{~m}$ elevation range in the three HKH ranges. The in-situ observations of snow, glaciers and climate by altitude need to be strengthened as a base for improved understanding of interactions between different parameters and to aid snow/ice melt runoff modeling. A detail hydrodynamic analysis of the Himalayan cryosphere is essential for sustainable water resource management under changing climate and land use conditions in this region in future. 


\section{References}

[1] Ahsan M, Shakir AS, Zafar S \&Nabi G (2016) Assessment of Climate change and variability in temperature, precipitation and flows in Upper Indus Basin. International Journal of Scientific and Engineering Research 7(4), 1610-1620.

[2] Ashraf A \& Batool A (2019) Evaluation of glacial resource potential for sustaining kuhl irrigation system under changing climate in the Himalayan region. Journal of Mountain Science 16(5), 1150-1159. https://doi.org/10.1007/s11629-018-5077-0.

[3] Ashraf A \& Iqbal A (2018) Influential aspects of glacial resource for establishing Kuhl system (gravity flow irrigation) in the Hindu Kush, Karakoram and Himalaya ranges. Science of the Total Environment 636, 487-499. https://doi.org/10.1016/j.scitotenv.2018.04.281.

[4] Bajracharya SR, Maharjan SB, Shrestha F, et al. (2015) the glaciers of the Hindu Kush Himalayas: Current status and observed changes from the 1980s to 2010. International Journal of Water Resources Development 31(2), 161-173. https://doi.org/10.1080/07900627.2015.1005731.

[5] Bolch T, Kulkarni A, Kaab A, et al. (2012) the State and Fate of Himalayan Glaciers. Science 336, 310-314. https://doi.org/10.1126/science.1215828.

[6] Bookhagen B \& Burbank DW (2010) toward a complete Himalayan hydrological budget: Spatiotemporal distribution of snowmelt and rainfall and their impact on river discharge. Journal of Geophysical Research-Earth Surface 115, 1-25. https://doi.org/10.1029/2009JF001426.

[7] Braithwaite RJ, Raper S, Chutko K (2006) Accumulation at the equilibrium-line altitude of glaciers inferred from a degree-day model and tested against field observations. Annals of Glaciology 43, 329-334. https://doi.org/10.3189/172756406781812366.

[8] Cramer T (1993) Climatological investigation in Bagrot valley. Cultural Area Karakoram Newsletter 3, 19-22. Tubingen, Germany.

[9] Fang JY \& Yoda K (1988) Climate and vegetation in China: changes in the altitudinal lapse rate of temperature and distribution of sea level temperature. Ecological Research 3, 37-51. https://doi.org/10.1007/BF02348693.

[10] Forsythe N, Kilsby CG, Fowler HJ, Archer DR (2010) Assessing climate pressures on glacier-melt and snowmelt-derived runoff in the Hindu Kush-Karakoram sector of the Upper Indus Basin. International Symposium on Managing Consequences of a Changing Global Environment. Newcastle, UK: British Hydrological Society, 1-8. https://doi.org/10.7558/bhs.2010.ic10.

[11] Forsythe N, Kilsby CG, Fowler HJ, et al. (2012) Assessment of Runoff Sensitivity in the Upper Indus Basin to Interannual Climate Variability and Potential Change Using MODIS Satellite Data Products. Mountain Research and Development 32(1), 16-29. https://doi.org/10.1659/MRDJOURNAL-D-11-00027.1.

[12] Fujita K (2008) Effect of precipitation seasonality on climatic sensitivity of glacier mass balance. Earth and Planet Science Letters 276(1-2), 14-19. https://doi.org/10.1016/j.eps1.2008.08.028.

[13] Gardelle J, Berthier E, Arnaud Y, Kääb A (2013) Region-wide glacier mass balances over the Pamir-Karakoram-Himalaya during 1999-2011. The Cryosphere 7, 1263-1286. https://doi.org/10.5194/tc-7-1263-2013.

[14] Hewitt K (2005) the Karakoram Anomaly? Glacier expansion and the elevation affect, Karakoram Himalaya. Mountain Research and Development 25, 332-340. https://doi.org/10.1659/0276-4741(2005)025[0332:TKAGEA]2.0.CO;2.

[15] Heynen M, Miles E, Ragettli S, et al. (2016). Air temperature variability in a high-elevation Himalayan catchment. Annals of Glaciology 57 (71), 212-222. https://doi.org/10.3189/2016AoG71A076.

[16] Hock R (2005) Glacier melt: A review of processes and their modelling. Progress in Physical Geography 29 , $362-391$. https://doi.org/10.1191/0309133305pp453ra.

[17] ICIMOD (2011) Status of Glaciers in the Upper Indus Basin. ICIMOD Report, Kathmandu, Nepal.

[18] Immerzeel WW, Beek LPHv., Bierkens MFP (2010) Climate change will affect the Asian water towers. Science 328, 1382-1385 https://doi.org/10.1126/science.1183188.

[19] Immerzeel WW, Petersen L, Ragettli S, Pellicciotti F (2014) the importance of observed gradients of air temperature and precipitation for modeling runoff from a glacierized watershed in the Nepalese Himalayas. Water Resources Research 50(3), 2212-2226. https://doi.org/10.1002/2013WR014506.

[20] IPCC (2014) Summary for policymakers. In: Field CB, Barros VR, Dokken DJ, Mach KJ, Mastrandrea MD, Bilir TE, Chatterjee M, Ebi KL, Estrada YO, Genova RC, Girma B, Kissel ES, Levy AN, MacCracken S, Mastrandrea PR, White LL (eds) Climate Change 2014: Impacts, Adaptation, and Vulnerability.Part A: Global and Sectoral Aspects. Contribution of Working Group II to the Fifth Assessment Report of the Intergovernmental Panel on Climate Change, Cambridge University Press, Cambridge, UK and New York, NY, USA, pp 1-32.

[21] Kääb A, Berthier E, Nuth C, Gardelle J, Arnaud Y (2012) Contrasting patterns of early $21^{\text {st }}$ century glacier mass change in the Hindu KushKarakoram-Himalaya. Nature 488, 495-498. https://doi.org/10.1038/nature11324.

[22] Kargel JS, Cogley JG, Leonard GJ, Haritashya U, Byers A (2011) Himalayan glaciers: The big picture is a montage. Proceedings of the National Academy of Sciences 108 (36), 14709-14710. https://doi.org/10.1073/pnas.1111663108.

[23] Kaser G, Großhauser M, Marzeion B (2010) Contribution potential of glaciers to water availability in different climate regimes. Proceedings of the National Academy of Sciences 107(47), 20223-20227. https://doi.org/10.1073/pnas.1008162107.

[24] Kattel DB, Yao T, Yang K, et al. (2013) Temperature lapse rate in complex mountain terrain on the southern slope of the central Himalayas. Theoretical and Applied Climatology, 671-682. https://doi.org/10.1007/s00704-012-0816-6.

[25] Khan MI (2014) GLOF Risk Reduction Guidelines for Gilgit-Baltistan Pakistan. Pakistan Glacial Lake Outburst Floods (GLOF) Project, Climate Change Division, Islamabad.

[26] Liu X, Cheng Z, Yan L, Yin ZY (2009) Elevation dependency of recent and future minimum surface air temperature trends in the Tibetan Plateau and its surroundings. Global and Planetary Change 68(3), 164-174. https://doi.org/10.1016/j.gloplacha.2009.03.017.

[27] Lundquist J, Pepin N, Rochoford C (2008) Automated algorithm for mapping regions of cold air pooling in complex terrain. Journal of Geophysical Research 113 (D22), D22107. https://doi.org/10.1029/2008JD009879.

[28] Lutz AF, Immerzeel WW, Shrestha AB, Bierkens MFP (2014) Consistent increase in High Asia's runoff due to increasing glacier melt and precipitation. Nature Climate Change (4), 587-592. https://doi.org/10.1038/nclimate2237.

[29] Mayer C, Lambrecht A, Belo M, et al. (2006) Glaciological characteristics of the ablation zone of Baltoro glacier, Karakoram. Annals of Glaciology 43(1), 123-131. https://doi.org/10.3189/172756406781812087.

[30] Mihalcea C, Mayer C, Diolaiuti G, et al. (2006) Ice ablation and meteorological conditions on the debris-covered area of Baltoro glacier, Karakoram, Pakistan. Annals of Glaciology 43(1), 292-309. https://doi.org/10.3189/172756406781812104.

[31] Mir RA, Jain SK, Jain SK, et al. (2017) Assessment of Recent Glacier Changes and Its Controlling Factors from 1976 to 2011 in Baspa Basin, Western Himalaya. Arctic, Antarctic, and Alpine Research 49:4, 621-647. https://doi.org/10.1657/AAAR0015-070.

[32] Mir RA, Jain SK, Saraf AK, Goswami A (2015) Decline in snowfall in response to temperature in Satluj basin, western Himalaya. Journal of Earth System Science 124(2), 365-382. https://doi.org/10.1007/s12040-015-0539-z.

[33] MRI Mountain Research Initiative EDW Working Group (2015) Elevation-dependent warming in mountain regions of the world. Nature Climate Change 5, 424-430. https://doi.org/10.1038/nclimate2563.

[34] Mukhopadhyay B \& Dutta A (2010) A stream water availability model of Upper Indus Basin based on a topologic model and global climatic datasets. Water Resources Management 24, 4403-4443. https://doi.org/10.1007/s11269-010-9666-0.

[35] NASED (2003) Northern Areas State of Environmental \& Development, (2003). Govt of Pakistan and IUCN Pakistan.

[36] Nüsser M, Dame J, Parveen S, Kraus B, Baghel R, Schmidt S (2019) Cryosphere-Fed Irrigation Networks in the Northwestern Himalaya: Precarious Livelihoods and Adaptation Strategies Under the Impact of Climate Change. Mountain Research and Development 39(2). https://doi.org/10.1659/MRD-JOURNAL-D-18-00072.1. 
[37] Ouyang H (2012) Climate Changes and Water Resources Management in the HKH region: Strategy and Implementation. Paper Presented at ICIMOD-MAIRS joint International Workshop on Climate Change Impacts on Water/Land and Adaptation Strategies in the Tibet-Himalayan Region, Pokhara, Nepal, 27 - 29 June 2012

[38] Pepin NC (2001) Lapse rate changes in northern England. Theoretical and Applied Climatology 68, 1-16. https://doi.org/10.1007/s007040170049.

[39] Petersen L, Pellicciotti F (2011) Spatial and temporal variability of air temperature on melting glaciers: a comparison of different extrapolation methods and their effect on melt modelling, Juncal Norte Glacier, Chile. Journal of Geophysical Research 116 (D23), D23109. https://doi.org/10.1029/2011JD015842.

[40] Pratap B, Dobhal DP, Bhambri R, Mehta M, Tewari VC (2015) Four decades of glacier mass balance observations in the Indian Himalaya. Regional Environmental Change, 16(3), 643-658. https://doi.org/10.1007/s10113-015-0791-4.

[41] Pritchard HD (2017) Asia's glaciers are a regionally important buffer against drought. Nature 545(7653), 169-174. https://doi.org/10.1038/nature22062.

[42] Rangwala I, Miller JR, Russell GL, Xu M (2010) Using a global climate model to evaluate the influences of water vapor, snow cover and atmospheric aerosol on warming in the Tibetan Plateau during the twenty-first century. Climate Dynamics 34(6), 859-872. https://doi.org/10.1007/s00382-009-0564-1.

[43] Rasul G \& Chaudhry QZ (2006) Global warming and expected snowline shift along Northern Mountains of Pakistan. Proceeding of $1^{\text {st }}$ Asiaclic Symposium Yokohama, Japan.

[44] Ren J, Jing Z, Pu J \& Qin X (2006) Glacier variations and climate change in the central Himalaya over the past few decades. Annals of Glaciology 43, 218-222. https://doi.org/10.3189/172756406781812230.

[45] Savoskul OS \& Smakhtin V (2013) Glacier systems and seasonal snow cover in six major Asian river basins: hydrological role under changing climate. Colombo, Sri Lanka: International Water Management Institute (IWMI). 53p. (IWMI Research Report 150). https://doi.org/10.5337/2013.204.

[46] SDPI (2002) Impact of Trade Liberalisation on Lives and Livelihood of Mountain Communities in the Northern Areas of Pakistan. Sustainable Development Policy Institute, Islamabad.

[47] Shekhar MS, Chand H, Kumar S, et al. (2010) Climate-change studies in the western Himalaya. Annals of Glaciology 51, $105-112$. https://doi.org/10.3189/172756410791386508.

[48] Singh P, Ramasastri KS, Kumar,N (1995) Topographical influence on precipitation distribution in different ranges of Western Himalayas. Hydrology Research 26, 259-284. https://doi.org/10.2166/nh.1995.0015.

[49] Tahir AA, Chevallier P, Arnaud Y, Ahmad B (2011) Snow cover dynamics and hydrological regime of the Hunza River basin, Karakoram Range, Northern Pakistan. Hydrological Earth System Science (HESS) 15 (7), 2275-2290. https://doi.org/10.5194/hess-15-2275-2011.

[50] Vender Velde EJ (1989) Irrigation management in Pakistan Mountain Environment, Colombo, Sri Lanka: International Irrigation Management Institute, Country Paper- Pakistan3, IIMIxx 48p.

[51] WAPDA (1988) Northem areas regional development plan reconnaissance repon. Gilgit District. (Main Report and Appendix 1) Lahore. Pakistan: The Water and Power Development Authority (Regional Planning Directorate, Planning Division, Water Resources Planning).

[52] Winiger M, Gumpert M, Yamout H (2005) Karakoram-Hindukush-Western Himalaya: Assessing high-altitude water resources. Hydrological Processes 19, 2329-2338. https://doi.org/10.1002/hyp.5887.

[53] WWF (2005) an Overview of Glaciers, Glacier Retreat, and Subsequent Impacts in Nepal. India and China. World Wildlife Fund, Nepal Program, March, 70 pp.

[54] Yao T, Thompson L, Yang W, et al. (2012) Different glacier status with atmospheric circulations in Tibetan Plateau and surroundings. Nature Climate Change 2, 663-667. https://doi.org/10.1038/nclimate1580.

[55] Zulfiqar M, Abbasi I, Khan H, et al. (2019) Agricultural Economy of Skardu is based on Glaciers and Snow Melting -A Case Study of Burgay Watershed. Sarhad Journal of Agriculture 35(2), 336-341. https://doi.org/10.17582/journal.sja/2019/35.2.336.341. 